\title{
Plio-Pleistocene geological record and small mammal faunas, eastern shore of the Azov Sea, Southern European Russia
}

\author{
Alexey S. Tesakov ${ }^{\mathrm{a}, *}$, Andrey E. Dodonov ${ }^{\mathrm{a}}$, Vadim V. Titov ${ }^{\mathrm{b}}$, Valery M. Trubikhin ${ }^{\mathrm{a}}$ \\ ${ }^{a}$ Geological Institute, Russian Academy of Sciences, Pyzhevsky 7, Moscow 119017, Russia \\ ${ }^{\mathrm{b}}$ Taganrog State Pedagogical Institute, R. Luxemburg 38, 20, Taganrog 347900, Russia
}

Available online 17 November 2006

\begin{abstract}
The shoreline of the Taganrog Gulf of the Azov Sea at the mouth of Don River provides a series of extended Upper Pliocene and Quaternary sections that have been actively studied in the last century. This extraglacial region had a complex sedimentary history combining subaerial aggradation with marine, fluvial, and deltaic sedimentation. The well-exposed stratigraphical sequence and abundant palaeontological record continuously attract geologists and highlight the region as one of international importance for the addressing of numerous problems of Late Pliocene and Quaternary stratigraphy and palaeogeography. Fossil mammalian faunas of the region include important Eurasian biostratigraphical markers such as Stenocranius ex gr. hintoni-gregaloides, Lagurini spp., and Mimomys savini. For many years, fossil remains of mammals provide decisive clues to the geological history of the region. Recent geological studies of reference sections have provided data on small mammals, palaeomagnetism and palaeogeographical reconstructions in the northeastern part of the Azovian Region. Mammalian assemblages indicate the presence of the Late Pliocene, late Early Pleistocene, Middle Pleistocene and Late Pleistocene levels and, in addition, provide a clear biostratigraphical context for the Early Middle Pleistocene transition.
\end{abstract}

(C) 2006 Published by Elsevier Ltd.

\section{Introduction}

The eroding shoreline of the Taganrog Gulf of the Azov Sea provides numerous outcrops of Upper Neogene and Quaternary deposits (Figs. 1, 2). Fossil mammalian faunas have an important role in the study of the area and recognition of the stratigraphical structure of the sedimentary sequence (Popov, 1948; Lebedeva, 1965, 1972; Velichko et al., 1973; Velichko, 1975; Markov, 1976; Markova, 1982, 1990; Rekovets, 1994; Bajgusheva et al., 2001). The lack of detailed geological documentation of small mammalian sites in the previous studies hindered effective biostratigraphical control. Moreover, insufficient application of palaeomagnetic studies in the past left many questions open as to the stratigraphical subdivision of the Upper Pliocene and Quaternary deposits. The authors have tried to improve these data. The most important sections are reviewed

\footnotetext{
${ }^{*}$ Corresponding author.

E-mail address: tesak@ginras.ru (A.S. Tesakov).
}

according to their stratigraphical succession, suggested by the new geological and palaeomagnetic evidence, together with the detailed examination of the small mammal faunas. Small mammals were collected by the authors in the field during the late 1990s and, particularly, during the field campaigns of 2002-2005. The analysis is further added by the materials collected in the region by L.P. Alexandrova, N.A. Lebedeva and Yu.M. Vasiliev in the 1960s and 1970s, and data from the literature.

As most Plio-Pleistocene mammal-based biostratigraphical studies in East Europe, this contribution is based on and refers to the system of mammal or faunal complexes of Gromov (1948). The regional zonal scale of MQR units (Pevzner et al., 2001) is also used.

In the text the authors use the international PliocenePleistocene boundary at $1.81 \mathrm{Ma}$, and the Lower-Middle Pleistocene boundary at the level close to the base of the Cromerian, that roughly corresponds with the boundary between the Tamanian and Tiraspolian mammal assemblages of Eastern Europe. 


\section{Geological setting}

The northeastern part of the Azov Sea Region includes the lower Don Valley and coastal area of the Taganrog Gulf (Fig. 1). Tectonically, this territory belongs to the northern flank of the Azovian-Kubanian Depression, bordered in the north by the submerged Azovian-Rostovian segment of the eastern extension of the Ukrainian Shield. In the studied area, the Pliocene-Pleistocene strata overlie Middle-Upper Miocene marine deposits. According to the geological structure and genetic properties, the Upper Pliocene and Quaternary deposits are subdivided into four units.

The Upper Pliocene and Lower Pleistocene marine sediments (Kujalnikian and Apsheronian) occupy the most tectonically depressed area in the southern part of studied territory in the Eisk Peninsula area and only known in boreholes (Popov, 1948; Rodzyanko, 1967). To the northeast, along the cliff between the Port Katon and Kagal'nik

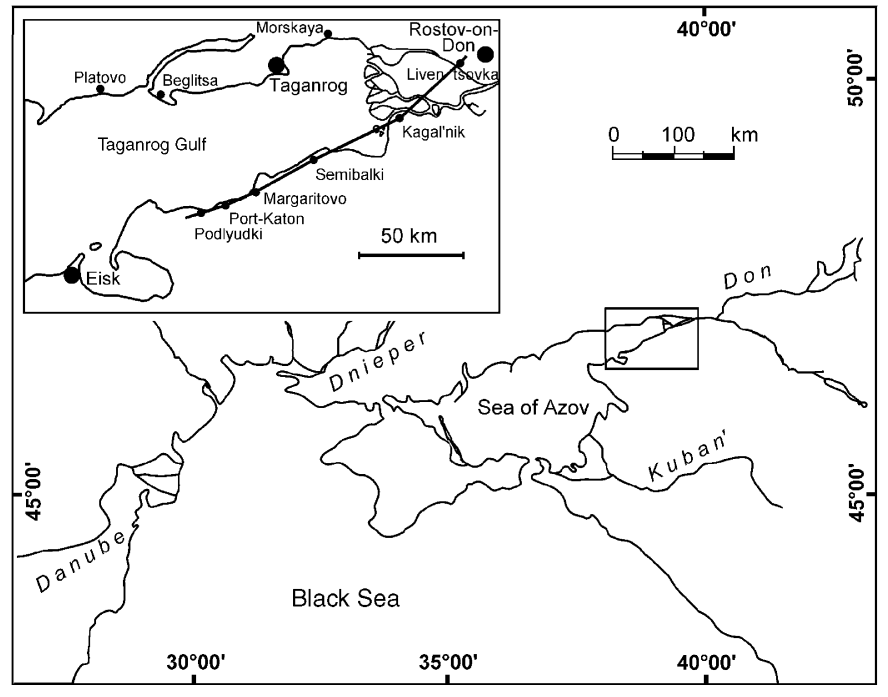

Fig. 1. Map of the geological localities studied in the northeast of the Azov Sea area. settlements only the upper part of the Lower Pleistocene lagoon deposits outcrops, whereas the Late Pliocene is represented by a fluvial series on the right bank of the palaeo-Don Valley.

The lower Middle Pleistocene fluvial-deltaic series outcrops between Chumbur-Kosa and Kagal'nik. The upper Middle Pleistocene and Upper Pleistocene loess-palaeosol series is developed as a regionally continuous cover that interfingers with the subaqueous formations. The recent (Holocene) alluvial-deltaic sediments of the Don River are exposed between Kagal'nik settlement and the city of Rostov-on-Don (Fig. 2).

Three main terrace levels have been identified in the coastal area (Lebedeva, 1972; Velichko et al., 1973; Velichko, 1975). The highest, the Khaprovian terrace of $40-45 \mathrm{~m}$ a.s.1. is formed with Upper Pliocene sediments. It is developed on the right bank of the palaeo-Don River Valley. In the terminology of Velichko (1975), it corresponds to the Melekino level which consists of lagoonalmarine sediments at the base of sections exposed along the northern coast of the Azov Sea. Another terrace is arbitrary established at a height of $30 \mathrm{~m}$. It is composed of upper Lower Pleistocene lagoon deposits. This Margaritovo terrace occurs along the southeastern coastal area of the Taganrog Gulf or the Nagaisk level of the northern coast of the Azov Sea. The next, topographically lower level is associated with the Middle Pleistocene fluvialdeltaic or lagoon sediments and is termed the Platovo or Semibalki terrace. The height of the latter is not more than 20-25 $\mathrm{m}$ a.s.1.

\section{Stratigraphical units and reference sections}

\subsection{Upper Pliocene fluvial deposits of the northern coast}

The Upper Pliocene deposits of the region are represented by extensive fluvial deposits mapped as the Khapry Formation. The Khapry Formation outcrops along the

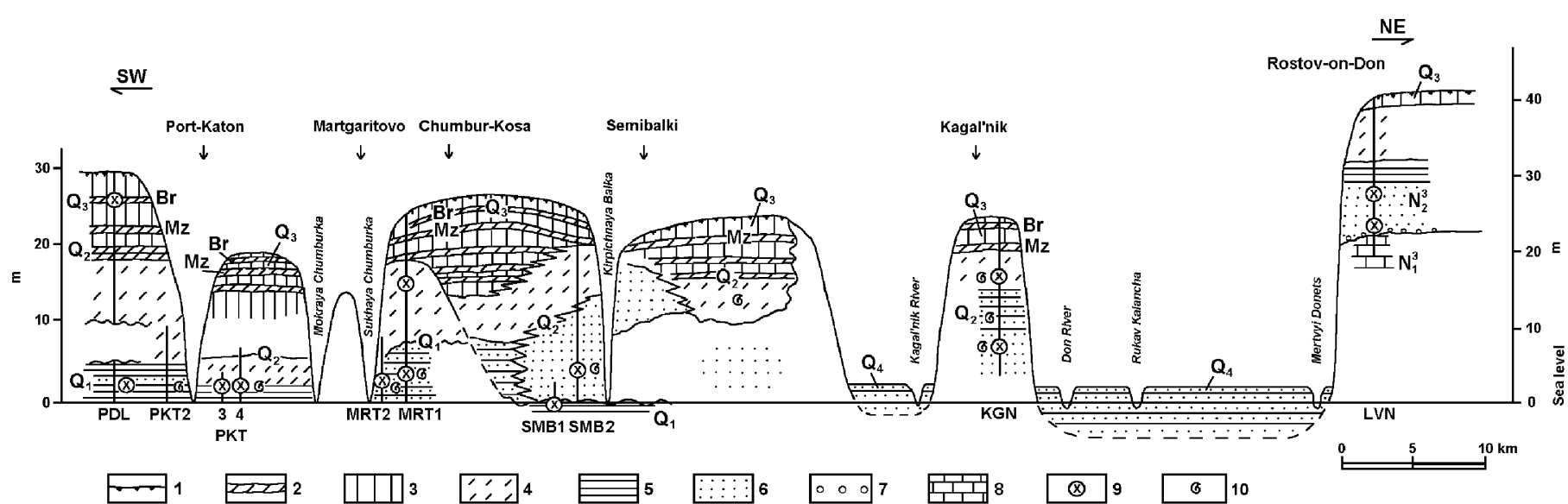

Fig. 2. Geological profile along the southeastern shoreline of the Taganrog Gulf and the mouth of the River Don. (1) modern soil; (2) palaeosol; (3) loess; (4) loam; (5) clay; (6) sand; (7) gravel; (8) limestone; (9) mammal fauna; (10) molluscan fauna. Sections: PDL; Podlyudki; PKT; Port-Katon; MRT; Margaritovo; SMB; Semibalki; KGN; Kagal'nik; LVN, Liventsovka. Palaeosols: Br, Bryansk; Mz, Mezin. 
northern coast of the Taganrog Gulf and the right bank of the lower Don River. The deposits consist of light quartz sands with clayey and gravelly interbeds. They rest on eroded Upper Miocene Maeotian and Pontian limestones and are overlain by variegated 'Scythian clays', which are palaeomagnetically referred to the upper Matuyama and early Bruhnes Chron. In all the sections studied, the deposits of the Khapry Formation are reversely magnetised. In the parastratoptype, the Liventsovka sandpit in the western suburbs of Rostov-on-Don, these deposits yielded a rich fauna of large and small mammals. Several natural exposures of the Khapry Formation occur in the cliff of the northern coast of the Azov Sea. Mammalian faunas suggest polycyclic formation of the Khapry deposits from the late Middle to Late Pliocene. Small mammal assemblages within these deposits have been referred to the Khaprovian and Psekupsian faunal complexes. The currently exposed sections contain fossils of the uppermost part of the faunal sequence dominated by hypsodont rhizodont arvicolids Borsodia ex gr. newtoni-arankoides (Tesakov, 2004).

Extensive sand pits on the western outskirts of Rostovon-Don (Figs. 1, 2) have provided excellent exposures of the fluvial Khapry deposits since mid 20th century. Large mammals from these exposures have been studied by Gromov (1948), Bajgusheva (1971) and others. Recently, Titov (1999) revised the megafauna.

The small mammals from this sequence were studied by Schevtschenko (1965), Agadjanian (1976), and Alexandrova (1976). Important small mammal collections have been also obtained by A. Krukover (in the 1980s), and recently by Titov and Tesakov. Tesakov (2004) revised the small mammals from the section. After the former large sand pit in Liventsovka was closed in the early 1990s, there were no extensive excavations for almost 10 years. Resumption of construction operations in Rostov in the first years of the 21 st century has led to the reopening of the sand pit. The new Liventsovka pit is situated $2 \mathrm{~km}$ to the west of the previous one and is characterised by smaller and more temporary exposures.

This section, the Liventsovka West site $\left[47^{\circ} 13^{\prime} \mathrm{N}\right.$, $39^{\circ} 35^{\prime} \mathrm{E}$ ] was studied in 2002-2004. The description below is based on the most complete section studied in 2002 (Fig. $3)$. The following stratigraphy was described (upsection):

1. Whitish-yellow, sometimes cavernous limestone with banks of shell moulds of Congeria. Maeotian, Upper Miocene. Observed thickness 1-2 m.

2. Cross-bedded, coarse-grained polymictic quartz sands with gravel. Basal bed of the Upper Pliocene Khapry alluvium, thickness $0.5-1 \mathrm{~m}$.

3. Cross- and horizontally bedded fine-grained white quartz sands with occasional lenses of medium-grained sand. One or two $5-10 \mathrm{~cm}$ thick interbeds of dark-green clays occur in the upper part of the bed. The bed represents the main member of the Upper Pliocene Khapry alluvium; 7-9 m.
4. Alternation of platy clays and fine-grained sands, grey and white coloured with characteristic striped appearance. Carbonate concretions appear in the upper part of bed. Possible floodplain deposits of the Khapry alluvium; 3-5 m.

5. Grey-brown and red coloured clays and loams reworked by soil processes in the upper $3 \mathrm{~m}$; contain carbonate concretions and gypsum crystals. Lower Pleistocene clays formation ('Scythian clays'); 4-5 m.

6. Pale loess and recent chernozem-like soil $(0.5 \mathrm{~m})$ at the top; $1.5 \mathrm{~m}$.

The main difference of this outcrop from the older sections of Liventsovka is in its almost twofold thickness reduction of the fluvial Khapry member (ca. 10 vs. $20 \mathrm{~m}$ ) and the reduced thickness of Scythian clays, although the general structure is identical. The difference points to the position of the main incision of the Khapry Formation near the old Liventsovka sandpit. The section of Liventsovka West probably exposes the marginal zone of the ancient Don Valley close to its bedrock flank. Palaeomagnetic studies (Velichko et al., 1973; Markov, 1976 and new data) show reversed polarity within beds 2 to 5. Similarly, the Khapry strata are exposed in the Morskaya section (Fig. 3).

The small mammal fauna (Table 1, Fig. 4: 1) obtained from several levels of the Khapry sands in Liventsovka West is uniform and indicates a geologically rapid accumulation of this member. In all samples three main species co-occur: Borsodia ex gr. newtoni-arankoides, M. reidi and Clethrionomys kretzoii. According to Tesakov (2004), this fauna corresponds to the last Pliocene regional zone of Eastern Europe, MNR1 (concurrent range zone of Borsodia ex gr. newtoni-arankoides-M. pliocaenicus), the Psekupsian faunal complex and to the end of the European zone MN17. As noted above, the older deposits with the Khaprovian megafaunal assemblage (with Archidiskodon gromovi) from the beginning of MN17 are not present in the currently available sections.

\subsection{Lagoon deposits of the end of Lower Pleistocene}

These deposits occur at the bases of sections in the south and partly northern coast of the Taganrog Gulf and are of lagoonal and, to a lesser extent, fluvial origin. The name Port Katon beds was proposed for them by Rodzyanko (1967). This unit is mostly represented by clayey sediments of greyish-blue and greenish colour. It overlies submerged Apsheronian (Lower Pleistocene) sediments and is overlain by the loess-palaeosol formation. The Port Katon deposits are reversely magnetised. The remains of mammals are associated with bluish clays and ferruginous sands exposed near the settlements of Port Katon (Markova, 1990), Semibalki (Rekovets and Nadachowski, 1995) and Margaritovo (Dubrovo and Alexeev, 1964). The micromammal associations contain advanced forms of Allophaiomys, Lagurodon arankae and $M$. savini. These faunas are 


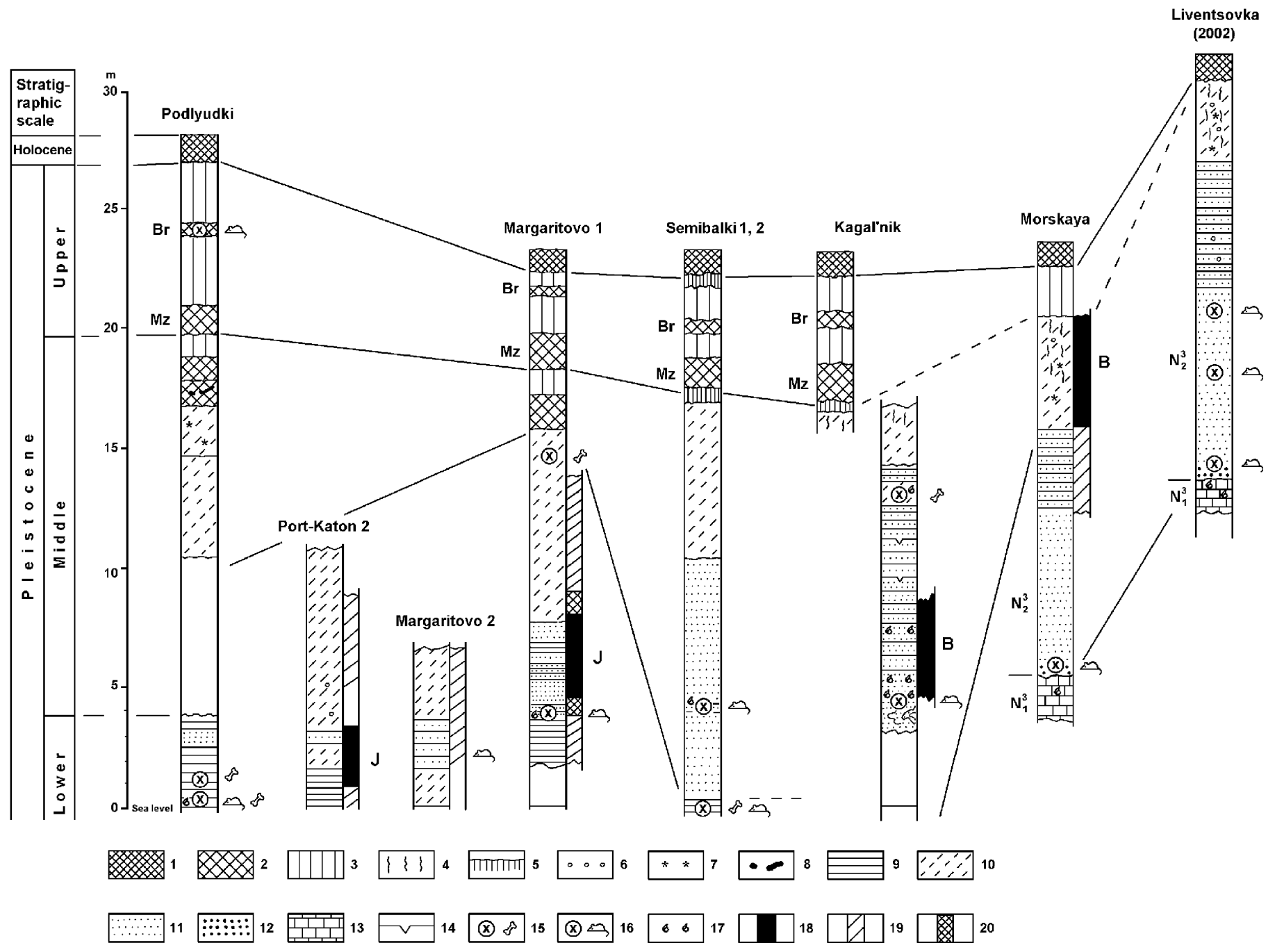

Fig. 3. Correlation of the Upper Pliocene-Quaternary sections in the northeast of the Azov Sea area. (1) modern soil; (2) fossil soil; (3) loess; (4) traces of palaeosol processes; (5) illuvial carbonate horizon; (6) carbonate concretions; (7) gypsum; (8) crotovinas; (9) clay; (10) loam; (11) sand; (12) gravel; (13) limestone; (14) traces of cryogenesis; (15) large mammal fauna; (16) small mammal fauna; (17) molluscan fauna; (18-20) palaeomagnetic polarity: (18) normal, (19) reversed, (20) anomalous; B, Brunhes Chron; J, Jaramillo Subchron.

referred to the Tamanian faunal complex of the later part of Early Pleistocene. The authors studied the sections near Margaritovo, Port Katon and Semibalki (Fig. 3).

\subsubsection{Margaritovo 1 and 2}

The main studied section, Margaritovo 1, is located $2 \mathrm{~km}$ NNE of the settlement of Margaritovo in the coastal cliff of the Azov Sea, [ $46^{\circ} 56^{\prime} \mathrm{N}, 38^{\circ} 52^{\prime} \mathrm{E}$ ] (Fig. 1). The following sequence is described (upsection):

1. Bluish-grey finely laminated clays; the sand lens in the upper part of the bed contains the remains of small mammals. Observed thickness, $2.5 \mathrm{~m}$.

2. Yellowish light grey sands horizontally laminated. Thickness, $1.5 \mathrm{~m}$.

3. Bluish-grey clays; $1-1.5 \mathrm{~m}$.

4. Yellowish light grey sands; $0.7 \mathrm{~m}$.

5. Greenish-grey loams; 8-9 m.

6. Loess-palaeosol series with three fossil soils; $7-9 \mathrm{~m}$.
Fig. 5 illustrates a part of the section below the loesspalaeosol series, beds $1-5$. The section is remarkable for the presence of a normal magnetic zone at the contact of bluish clays and greenish loams (Fig. 5A). This zone is interpreted as representing the Jaramillo Subchron. Analysis of diagrams of thermal demagnetisation for samples in Margaritovo 1 (Fig. 5B) shows that the characteristic component of magnetisation was revealed in the range of $300-400{ }^{\circ} \mathrm{C}$. The occurrence of a normally magnetised interval was also established at the base of the Port Katon 2 section (Fig. 3) between reversely magnetised sediments. This is also interpreted as representing the Jaramillo Subchron.

The lens of coarse-grained poorly sorted sands, cemented by carbonate, within the bluish clay in the upper part of the bed 1 have yielded a representative fauna of small mammals, Margaritovo 1 (Table 1, Fig. 4: 4-6, 10). The fauna is dominated by $M$. savini, and also contains advanced Allophaiomys ex gr. pliocaenicus, Lagurodon 


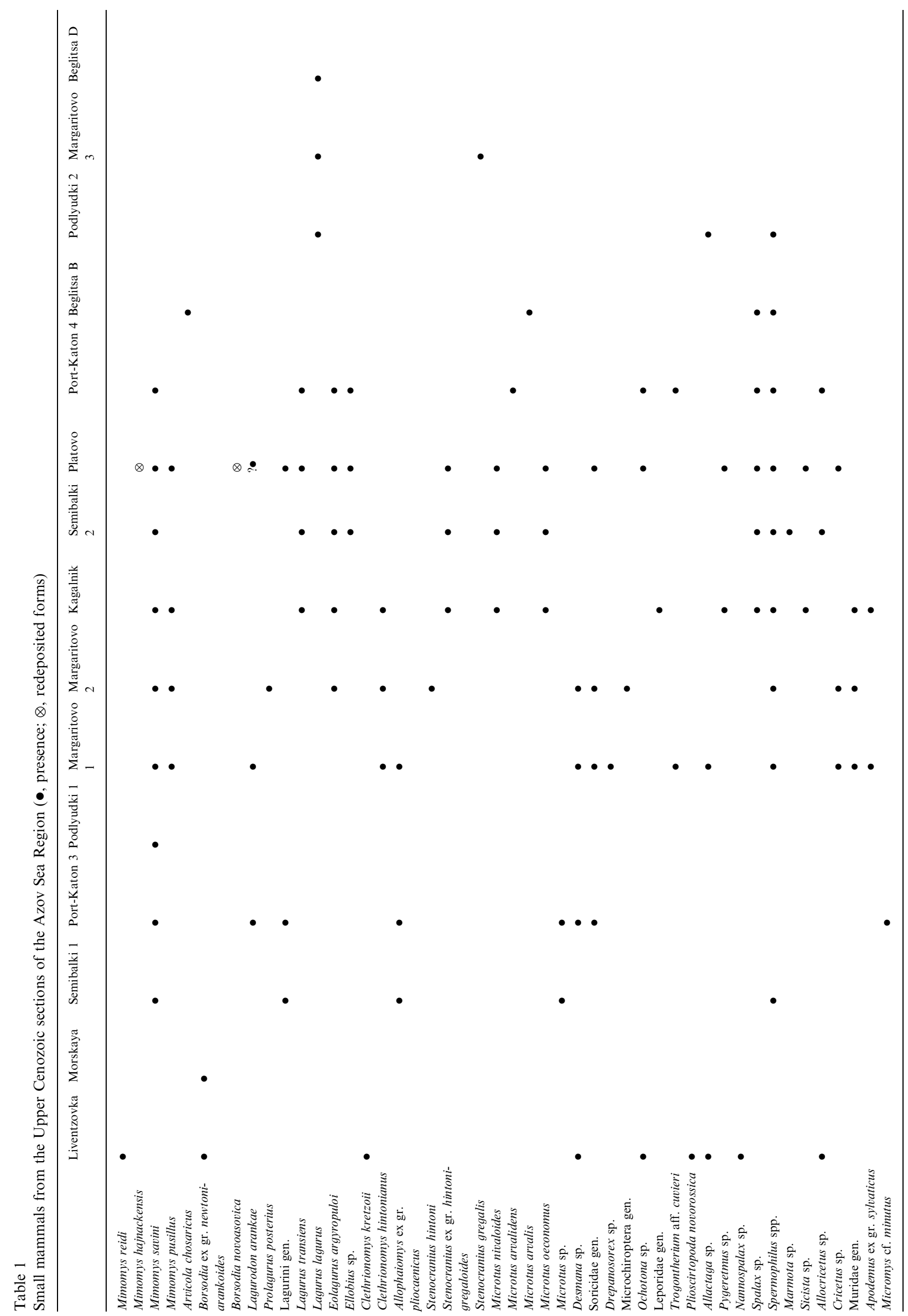




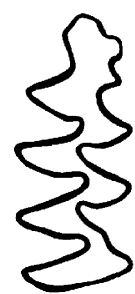

1

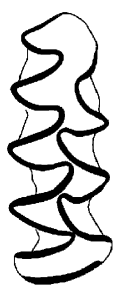

5

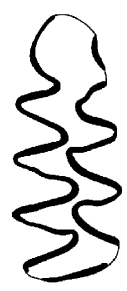

10

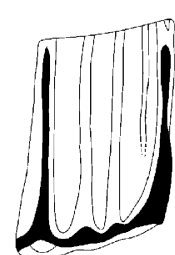

1 a

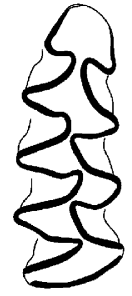

6

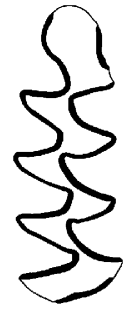

11

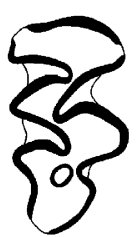

2

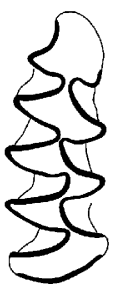

7

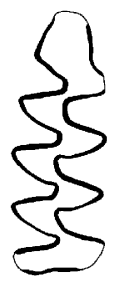

12

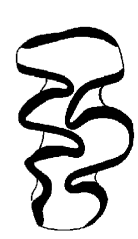

3

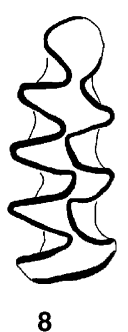

8

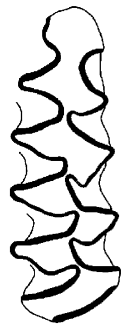

13
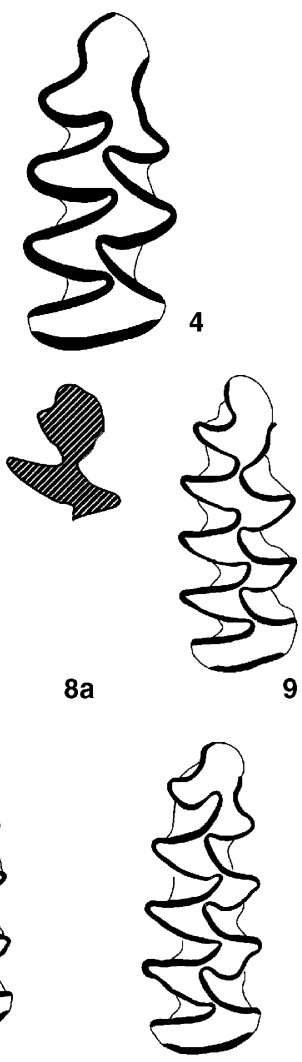

14

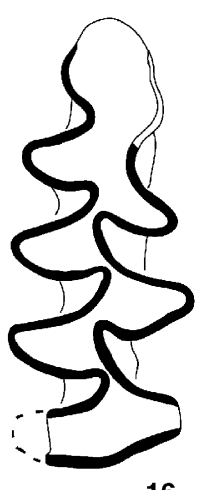

16
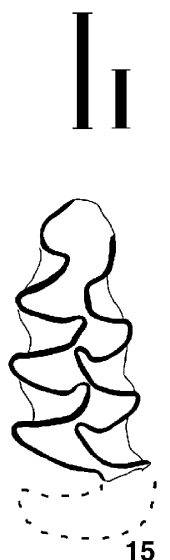

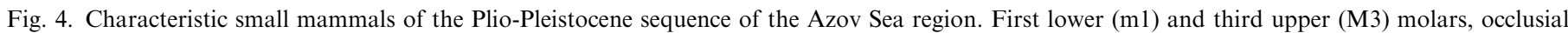

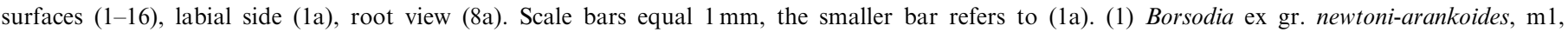

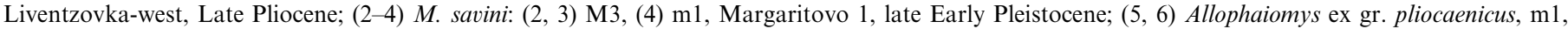

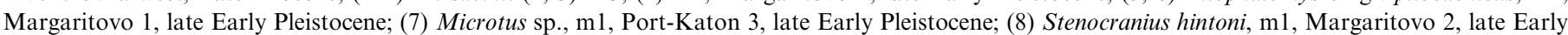

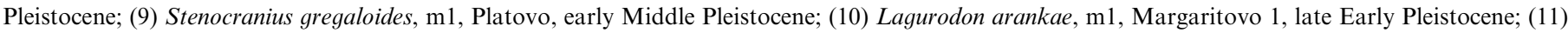

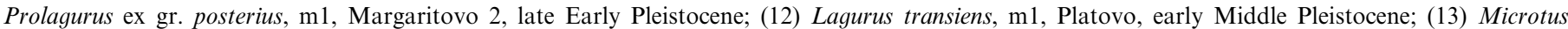

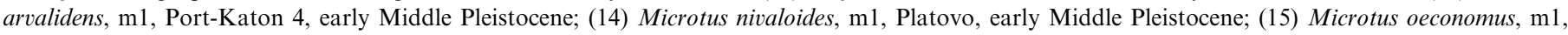
Platovo, early Middle Pleistocene; (16) Arvicola chosaricus, m1, Beglitsa B, late Middle Pleistocene.

arankae and Clethrionomys hintonianus. The composition and stage of evolution of the main elements are similar to the well-known faunas of Port Katon (Markova, 1982, 1990) and Korotoyak 3c (Iossifova and Semenov, 1998; Markova, 2005). The latter locality has also been shown to include the Jaramillo Subchron.

Another section, Margaritovo 2, was studied $1.2 \mathrm{~km} \mathrm{~N}$ of the settlement of Margaritovo, also in the coastal cliff of the Azov Sea, $\left[46^{\circ} 56^{\prime} \mathrm{N}, 38^{\circ} 52^{\prime} \mathrm{E}\right]$. The sequence within this section resembles that of the Margaritovo 1 section, the main difference being in the presence of thick member of ferruginous sands upon the bluish clays in the bottom, together with a reduced thickness of the upper part of the section.

The small mammal assemblage (Table 1, Fig. 4: 8, 11) was recovered from the cross-bedded, polymictic sands. This fauna is dominated by voles of the supergenus Microtus: Stenocranius hintoni. Smaller lagurines are represented by Prolagurus ex gr. posterius. The stratigraphical position and stage of evolution of Stenocranius imply a slightly younger geological age of this fauna compared to that of Margaritivo 1, which corresponds to the magnetically reversed interval above the Jaramillo Subchron (Fig. 3).

\subsubsection{Port Katon 3}

To the west of the Margaritovo sections a number of important sections are studied around the settlement of Port Katon (Fig. 1). The first rich small mammal fauna in this area was studied by Markova $(1982,1990)$. This fauna is referred to as Port Katon 1. According to Markova, the fauna originated from the sandy lens enriched in shells of molluscs among the bluish siltstones and clay exposed in the basal part of the cliff section immediately to the west from the settlement of Port Katon. This section is currently obscured by landslides.

The Port Katon 3 section, $\left[46^{\circ} 53^{\prime} \mathrm{N}, 38^{\circ} 45^{\prime} \mathrm{E}\right.$ ] is located in the coastal cliff, below the old cemetery of Port Katon, $500 \mathrm{~m} \mathrm{NE}$ of the settlement (Fig. 2).

The following stratigraphy is observed (upsection):

1. Bluish clays and silts; $3-5 \mathrm{~m}$.

2. Black and brownish clays and silts with abundant layers of redeposited and rolled carbonate concretions. The 


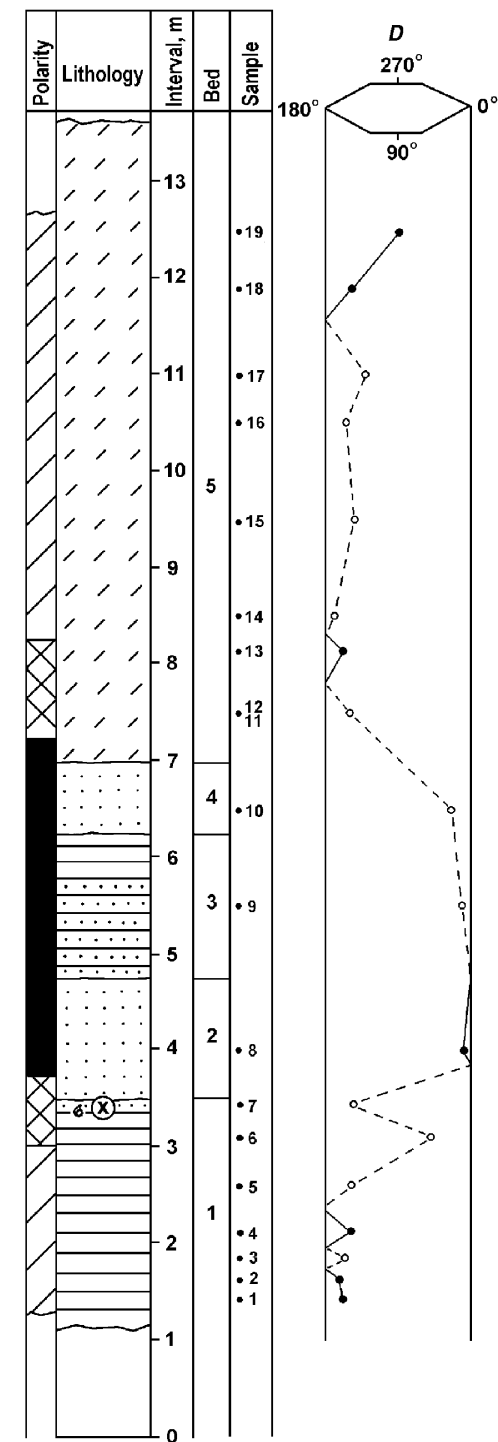

(A)
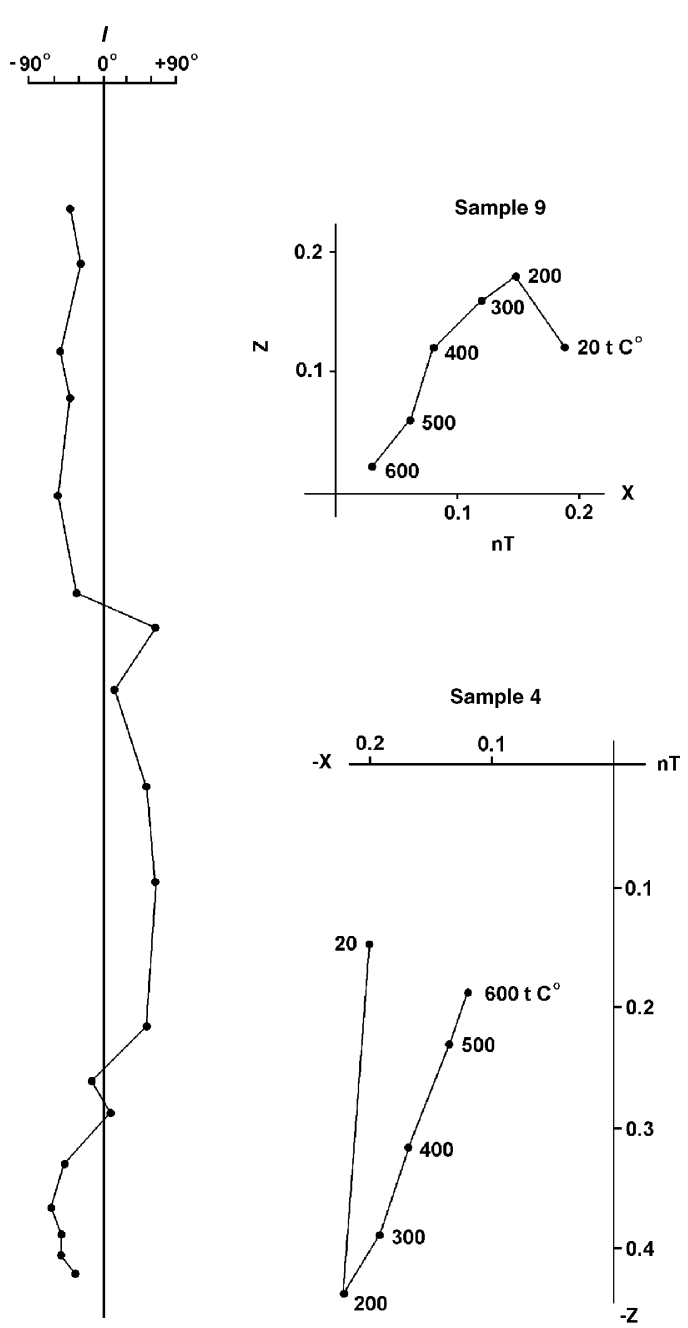

(B)

Fig. 5. Palaeomagnetic characteristics of the Margaritovo 1 section. (A) Palaeomagnetic stratigraphy of the Margaritovo 1 section: D, declination, I, inclination. (B) Diagrams of the thermal demagnetization of two samples. For lithological descriptions see Fig. 3.

bed overlies the clays of the bed 1 with an irregular boundary and occasional erosional pockets with shells of stagnophile aquatic molluscs and bones of small mammals; 4-6 m.

3. Subaerial sequence; 5-7 m.

Deeply incised pockets enriched with shells of freshwater molluscs, at the erosional boundary between beds 1 and 2, yielded remains of small vertebrates. The assemblage is dominated by fish bones, the small mammals are represented by dominant $M$. savini. The presence of advanced Allophaiomys and $L$. arankae allows the fauna to be assigned to the Tamanian assemblage. The fauna also include pitymyoid (non-hintonid) Microtus sp. (Fig. 4: 7). This faunal level is coeval with those of Margaritovo 1 and with Port Katon 1 of Markova $(1982,1990)$.

\subsubsection{Semibalki 1}

The section of Semibalki 1 , [ $46^{\circ} 59^{\prime} \mathrm{N}, 39^{\circ} 00^{\prime} \mathrm{E}$ ], is situated about $1 \mathrm{~km}$ to SW from the Glubokaya gully at the western margin of the Semibalki settlement, on the seashore (Fig. 1). The Lower Pleistocene bluish clays and silts, which contain abundant freshwater molluscks shells, outcrop at sea-level and are accessible for study only during occasional periods of low sea-level. Apart from characteristic small mammals (Rekovets, 1994; Rekovets and Nadachowski, 1995), this site has yielded important large mammal material (Bajgusheva et al., 2001), including Archidiskodon tamanensis. The authors' data confirm the presence in the small mammal fauna of Allophaiomys cf. pliocaenicus, pitymyoid Microtus sp., M. savini and lagurines.

The seashore sections near the settlement of Semibalki have yielded fossil mammals of two different time periods, 
i.e. late Early Pleistocene and early Middle Pleistocene. In order to avoid mixing of these localities in publications, it is proposed to label the former (Tamanian faunas) as Semibalki 1 and the latter (Tiraspolian faunas) as Semibalki 2.

\subsection{Fluvial deposits of lower Middle Pleistocene}

These deposits are represented by polymictic alluvialdeltaic sands that include abundant freshwater mollusc shells at Semibalki, Kagal'nik, Platovo and Port Katon 4. They overlie and partially incise into the Port Katon unit and are covered by a loess-palaeosol series. This formation is frequently referred to as the Semibalki terrace deposits. The deposits are normally magnetised in the Kagal'nik section. The small mammal associations include Lagurus ex gr. posterius-transiens, Microtus nivaloides, Stenocranius ex gr. hintoni-gregaloides, Eolagurus argyropuloi and other forms referred to the Tiraspolian faunal complex of the early Middle Pleistocene.

\subsubsection{Semibalki 2}

Small mammals from the sections near the Semibalki settlement were studied by Schevtschenko (1965) and Rekovets and Nadachowski (1995). In 2002 the authors studied the section directly SW of the gully with the public well at the western margin of the settlement, Semibalki 2 [46 $\left.59^{\circ} \mathrm{N}, 39^{\circ} 01^{\prime} \mathrm{E}\right]$ (Fig. 1).

The section has the following principal stratigraphy (upsection):

1. Bluish clays and silts; $0.5 \mathrm{~m}$.

2. Deltaic horizontally and cross-bedded polymictic sands. The lower part of the bed includes abundant freshwater mollusc shells and bones of small mammals; $10 \mathrm{~m}$.

3. Lagoonal greenish-grey 'tobacco' loams; 6-7 m.

The lagoonal-deltaic deposits are overlain by subaerial loess-palaeosol alternations.

The abundant small mammal fauna from the lower part of bed 2 is represented by the typical association of the Tiraspolian mammal complex which includes the predominant larger vole Microtus nivaloides together with primitive Lagurus transiens, the water vole M. savini, and others.

\subsubsection{Kagal'nik}

The Kagal'nik section $\left[47^{\circ} 05^{\prime} \mathrm{N}, 39^{\circ} 21^{\prime} \mathrm{E}\right]$ was studied in the sandpit $5 \mathrm{~km}$ to the WSW of the town of Azov (Fig. 1). The sandpit exposes the Platovo (= Semibalki) terrace deposits of the left bank of the Don Valley to the northeast from the mouth of the Kagal'nik River. The locality is famous for the finds of two skeletons of the throgontherine elephant, Mammuthus trogontherii in 1964 and 1998 (Bajgusheva and Timonina, 2001); the latest excavation campaign was carried out during the summer of 1999.
The Kagal'nik section (Fig. 3) consists of sandy and loamy members of deltaic-lagoon origin overlain by subaerial deposits. The following section was described during the excavations in 1999 (upsection):

1. Sands, light grey horizontally bedded with interbeds of dark grey silty clays. The lower part of the bed contains lenses of clayey sand with freshwater mollusc shells and bones of small mammals; $2 \mathrm{~m}$.

2. Alternation of light grey, fine-grained, cross- and horizontally bedded sands and brown grey clays. Clay interlayers contain mollusc shells; $3.5-3.7 \mathrm{~m}$.

3. Sands light grey, fine-grained, fine layered with thin interbeds of grey clays. The middle part of the bed is cryoturbated: an ice wedge pseudomorph penetrates the sand down to the depth of $0.6 \mathrm{~m} ; 2.5 \mathrm{~m}$.

4. Loamy sand light brown indistinctly bedded; $0.7-0.8 \mathrm{~m}$.

5. Loams dark brown with sparse green reddish gleyed spots, carbonate concretions $(\varnothing 2 \mathrm{~cm}$ ) and sparse shells of freshwater molluscs. The bed contained the skeleton of Mammuthus trogontherii; $0.5-0.8 \mathrm{~m}$.

6. Loams, dark brown, layered, contain fine carbonate concretions (diameter $2 \mathrm{~cm}$ ); $0.5 \mathrm{~m}$.

7. Loam, dark brown with carbonate concretions and fine iron and manganese grains (diameter $2-3 \mathrm{~cm}$ ), $2-3 \mathrm{~m}$.

Higher parts of the section are not exposed.

The elephant remains were confined to the loamy layer in the upper part of the section. The sandy deposits at the base of the section (bed 1) have yielded a characteristic association of small mammals. The mammalian fauna is almost identical to that known from the Tiraspolian strata at Semibalki: Microtus nivaloides, primitive Lagurus transiens and Stenocranius ex gr. hintoni-gregaloides. Only the lower (essentially clayey) layers in the Kagal'nik section, beds 1 and 2, could be measured palaeomagnetically and showed normal polarity. Of particular importance are the cryogenic structures seen in the clayey sands (bed 3) of the upper deltaic sequence at Kagal'nik. These structures are a good example of early periglacial processes in the Azov Sea region during the Middle Pleistocene. The association of the molluscs in bed 1 (Tchepalyga, personal communication) has a rheophilous appearance and contains shells of the extinct gastropod Viviparus tiraspolitanus (Pavl.) that was originally described from the so-called 'Tiraspol Gravel' fluvial deposits. These deposits forming the Kolkotov Terrace near the city of Tiraspol in Moldova, are the stratotype of the Tiraspolian mammal complex. The molluscan assemblages from beds 2 and 5 are of limnophilous and stagnophilous character and indicate a deltaic-lagoonal environment.

\subsubsection{Platovo}

The section on the northern bank of the Taganrog Gulf between the settlements Priazovskii and Veselo-Voznesen$\mathrm{ka}$ is traditionally called Platovo $\left[47^{\circ} 08^{\prime} \mathrm{N}, 36^{\circ} 21^{\prime} \mathrm{E}\right]$ (Fig. 1). This excellent long-exposed cliff section has been 
repeatedly studied by numerous researchers (Velichko et al., 1973; Markov, 1976). The general structure of the sedimentary sequence includes a lagoon-fluvial member $(5-6 \mathrm{~m})$ at the base, overlain by a thick loess and palaeosol member $(10-15 \mathrm{~m})$. The lower sands and gravels contain abundant remains of fresh- and brackish-water molluscs. Agadjanian (1976) reported two small mammal associations with Stenocranius gregaloides, Allophaiomys, Lagurus posterius-transiens and other forms from these sediments. $\mathrm{He}$ attributed both faunas to the Tiraspolian faunal complex. The authors studied this section in 2002-2005 and collected representative small mammal material (Table 1, Fig. 4: 9, 12, 14-15) from the lowermost lagoon-fluvial strata. The fauna is co-dominated by Stenocranius ex gr. hintoni-gregaloides and large Microtus nivaloides. Lagurus transiens, Microtus oeconomus and Eolagurus are also present. The remarkable feature of this assemblage is the presence of numerous redeposited forms of Middle Pliocene age, including M. hajnackensis and Borsodia novoasovica. This faunal association is known in situ $40 \mathrm{~km}$ to the W, near the settlement of Shirokino (Ukraine). The main Platovo fauna is very similar to the Tiraspolian faunas of Semibalki and Kagal'nik and the basal member of the Platovo section is assigned to the early Middle Pleistocene.

\subsubsection{Port Katon 4}

In 2003 the authors studied the cliff section about $1.5 \mathrm{~km}$ to the NE of the settlement of Port Katon. This section yielded small mammals that proved for the first time the presence of Middle Pleistocene deposits in the Port Katon area. These are most likely the infillings of a large gully deeply cut into the Lower Pleistocene Port Katon beds.

This section is referred to here as the Port Katon 4 $\left[46^{\circ} 53^{\prime} \mathrm{N}, 38^{\circ} 46^{\prime} \mathrm{E}\right]$ locality (Fig. 1), which is near Port Katon 3 (Fig. 2). It is represented by the following sequence (upsection):

1. Bluish silts and clays of the Port Katon lagoonal facies; $0.3-0.5 \mathrm{~m}$.

2. Brown gravelly and clayey sands and silts; $0.5-1 \mathrm{~m}$.

3 . Brown clays and silts with abundant reworked carbonate concretions and occasional mollusc shells; $>5 \mathrm{~m}$.

The clayey sands and gravels of bed 2 have yielded small mammal fauna remains (Table 1) together with shells of stagnophilous freshwater molluscs (Lymnaea, Planorbarius). The small mammals are dominated by Microtus arvalidens (Fig. 3: 13). Other indicative taxa are the very advanced $M$. savini, with some of its molars at rootless ontogenetic stage, and advanced Lagurus transiens. The assemblage is similar to the late Tiraspolian (early Middle Pleistocene) faunas. Palaeomagnetic measurements have demonstrated a normal polarity for beds $1-3$ in the section which are therefore assigned to the Brunhes Chron.

\subsection{Loess-palaeosol sequence}

The loess-palaeosol sequence caps the sections in the area studied. The sequence is normally magnetised and contains 4-5 loess-palaeosol depositional cycles (Lebedeva, 1972; Velichko et al., 1973). The basal cycles are poorly expressed, being replaced by the underlying lagoon or alluvial deposits. The two units assigned to the Bryansk and Mezin palaeosol horizons are recognisable in the Upper Pleistocene age interval. The Bryansk horizon is a light brown, weakly developed palaeosol, which is sometimes cut by the modern soil. Its ${ }^{14} \mathrm{C}$ date of $27-29 \mathrm{ka}$ was determined in an adjacent area of the northwest Black Sea coastal region, in the Roksolany and Tiraspol sections (Velichko et al., 1992; Dodonov et al., 2000). The Mezin pedocomplex, broadly correlated with the Eemian interglacial stage, consists of two palaeosols: the lower one is a dark brown humic soil; the upper is a light brown horizon. In the Beglitsa section $20 \mathrm{~km} \mathrm{~W}$ of Taganrog (Fig. 1), the discovery of a Mousterian core $1 \mathrm{~m}$ above the Mezin soil complex, and the presence of bone remains of an early form of Mammuthus primigenius below this complex, indicate a last interglacial age interval for the soil formation of this level (Ivanova and Praslov, 1963). The occurrence of the early form of Mammuthus primigenius is also documented below the Mezin soil complex in the Margaritovo section (Bajgusheva, personal communication). This early form of Mammuthus primigenius is characteristic of the late Dnieper glacial substage (late Saalian). Beneath the Mezin pedocomplex two or three brown palaeosols occur along the cliff at Podlyudki, Chumbur-Kosa, Semibalki and Pavlo-Ochakovo.

The small mammal remains in the loess-palaeosol series are poorly studied. They are sporadically known in the uppermost loess cycles which are referred to the Late Pleistocene at Platovo (Agadjanian, 1976), and also at Port Katon, Margaritovo 3, Pavlo-Ochakovo and Beglitsa (level D). The small mammals recovered so far (Stenocranius gregalis, Lagurus lagurus, Allactaga ex gr. jaculus, Pygeretmus sp., Spermophilus cf. pygmaeus) indicate dry, possibly periglacial steppe conditions. In the Beglitsa section below the Mezin pedocomlex, there is the first indication of the presence of the late Middle Pleistocene small mammal fauna (Beglitsa B) with Arvicola chasarisus (Fig. 4: 16) and Microtus arvalis.

\section{Discussion}

\subsection{Biostratigraphical record}

The small mammal record of the geological sequence studied shows an excellent succession from the Late Pliocene to Late Pleistocene (Fig. 6). However, several gaps in this record are obvious. So far, there are no reliable data from the intervals of the early and middle parts of the Early Pleistocene, and the beginning of late Middle Pleistocene. 


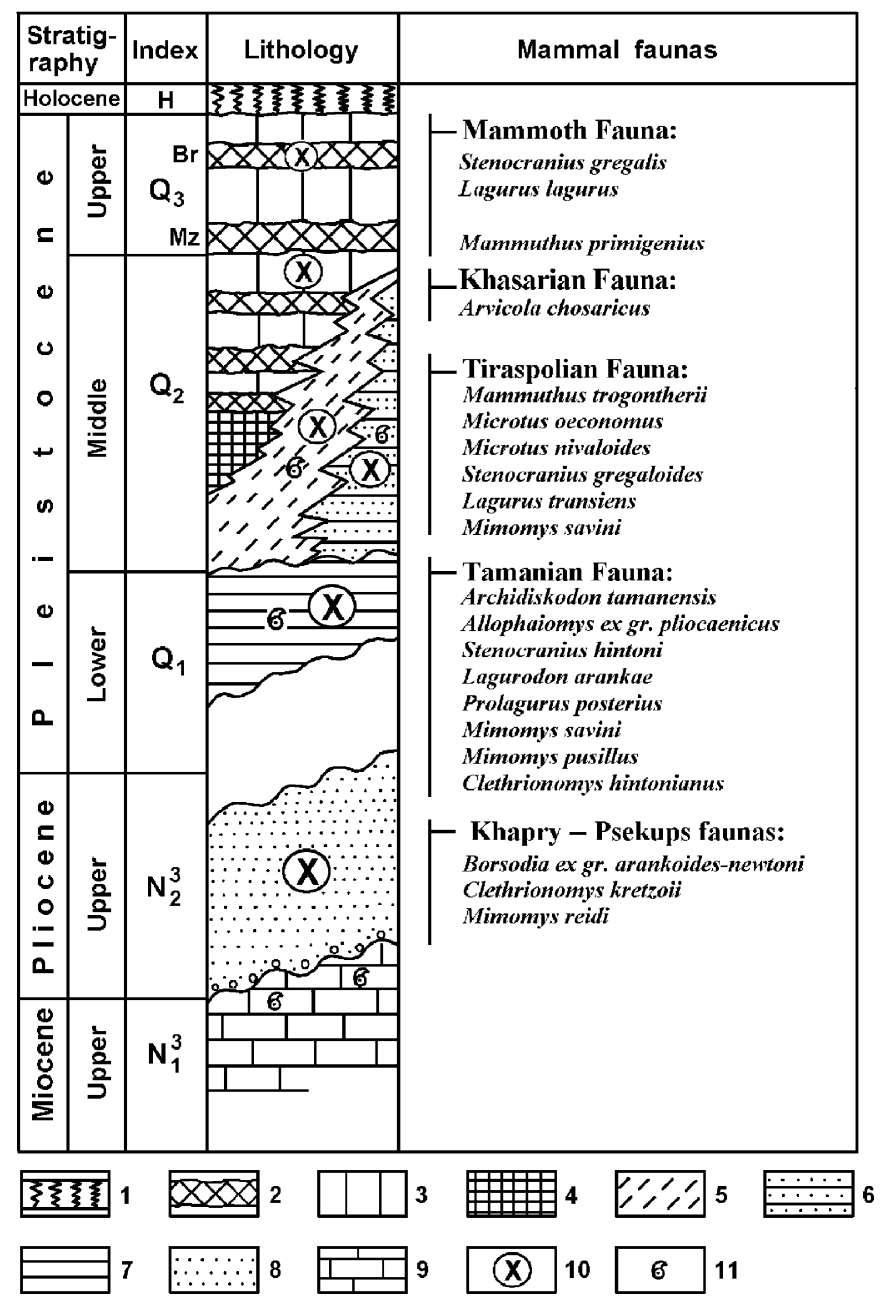

Fig. 6. Summary section of the Upper Pliocene and Pleistocene deposits outcropping in the northeast of the Azov Sea area. (1) modern soil; (2) palaeosol; (3) loess; (4) loam reworked by palaeosol processes; (5) Middle Pleistocene lagoonal deposits (loam and clay); (6) Middle Pleistocene alluvial and deltaic deposits (sands with clay interlayers); (7) Lower Pleistocene lagoon deposits (clays); (8) Upper Pliocene alluvial deposits (sands); (9) Upper Miocene limestone; (10) mammal fauna; (11) molluscan fauna.

Late Pliocene small mammals are well known from the multi-unit Liventsovka sequence (Schevtschenko, 1965; Alexandrova, 1976; Tesakov, 2004). Here the strong predominance of Borsodia in this sequence indicates the important role of open, steppe-like environment at that time. The evolutionary level of these ancient lagurines, with rooted dentitions ( $\mathrm{HH}$ or hypsodonty index of $\mathrm{m} 1>4$ ), suggests their attribution to Borsodia ex gr. newtoniarankoides and indicates the presence of the local zone MNR1 of the terminal Late Pliocene (Tesakov, 2004). The progressive hypsodonty increase of this lineage provides a most detailed biochronology of Middle-Late Pliocene faunas of the northern Black Sea region. Borsodia from the Liventsovka West section records the penultimate morphological stage before the complete loss of roots in molars and the transformation into rootless lagurines of the Early Pleistocene.
The earliest Early Pleistocene small mammalian faunas are very rare in the region studied. The only indication is the association of Allophaiomys cf. pliocaenicus and Lagurini that have been reported from the buried gully deposits, cut into the Khapry sand, in the classic Liventsovka sand pit section (Schevtschenko, 1965).

The faunas of the second half of the Early Pleistocene are well represented in the region and have been recovered from the basal lagoon bluish clays in sections of Port Katon and Margaritovo. The specific 'aquatic' appearance, with abundant stagnophilous molluscs, fish remains and small mammals dominated by the ancient water vole M. savini, are characteristic of these associations. M. savini of this level is distinct in its relatively small size (length of $\mathrm{m} 1$ ranging $2.8-3.2 \mathrm{~mm}$ ), common occurrence of primitive features, including enamel islets in younger $\mathrm{m} 1$ and even M3, relatively low dentine tracts (complete tracts uninterrupted by wear are regularly present in younger teeth with formed crown bases, especially in $\mathrm{m} 3$ and $\mathrm{M} 3$ ). Another primitive character, the 'mimomys ridge', however, occurs extremely rarely. Other aquatic mammals represented are Trogontherium cf. cuvieri and Desmana sp. In addition, mesic conditions are also indicated by the presence of shrews (Drepanosorex and Sorex), red-backed voles (Clethrionomys hintonianus), and wood and harvest mice (Apodemus and Micromys), the latter not found at any other Late Pliocene-Pleistocene levels sampled in the region. A much smaller part of these associations is represented by mammals of open, steppe-like habitats, such as lagurines Lagurodon arankae and Allophaiomys ex gr. pliocaenicus. The occurrence of a form of pitymyoid Microtus resembling M. thenii from Untermassfeld (Maul, 2001) or M. nutiensis is particularly remarkable. The new palaeomagnetic evidence shows that the Tamanian small mammal faunas of Port Katon predate the Jaramillo Subchron, contrary to the opinion of Kolfschoten and Markova (2005). The faunas reviewed are assigned to local biostratigraphical zone MQR8 (Pevzner et al., 2001).

An important chronologically younger small mammal fauna is present in the section of Margaritovo 2. This association, dated to the latest Early Pleistocene, contains primitive Stenocranius hintoni and Prolagurus ex gr. posterius. The first appearance datum of $S$. hintoni is believed to be an important biostratigraphical marker occurring between 1.1 and $0.8 \mathrm{Ma}$. The appearance of this species is most likely associated with a westwards transEurasian dispersal event. This is because no signs of its early evolution are known in faunas dating from the older part of Early Pleistocene in Eastern and Western Europe. During a relatively short time interval at the end of Early Pleistocene, S. hintoni, reported as Microtus gregaloides, reached as far as Spain (Cuenca-Bescós et al., 2001). Another important event is the extinction or considerable decline of previously abundant Lagurodon arankae and its replacement by somewhat less morphologically advanced Prolagurus posterius. In the biostratigraphical zonation schemes for Eastern Europe, faunas of this type are 
assigned to the Morozovka and Petropavlavka units and to local zone MQR7 (Pevzner et al., 2001).

The early Middle Pleistocene time interval is well represented in the region by the Tiraspolian small mammal fauna from the Kagal'nik, Semibalki 2 and Platovo sections. They show the characteristic association of primitive Lagurus transiens, Stenocranius gregaloides and Microtus nivaloides. These predominant forms are indicative of steppe-like landscapes. Among other forms of open biotopes are Eolagurus argyropuloi, Spermophilus sp., the first record of marmots, dipodines of the genus Pygeretmus and others. Mesophilous elements are much rarer and include Clethrionomys, Microtus oeconomus and M. savini. These faunas are attributable to the Tiraspolian faunal complex, most probably to its early stage, and to local biostratigraphical zones MQR6-5.

The final stages of the Tiraspolian mammal complex may be represented by the Port Katon 4 fauna. The microtoid group is represented here by Microtus arvalidens that is also typical of the advanced Tiraspolian faunas, including the type association of Kolkotova Balka. The very advanced evolutionary stages of the lagurines and $M$. savini also suggest the correlation of this assemblage with the Muchkapian horizon of the East European scheme and with local zone MQR5.

Late Middle Pleistocene small mammals are poorly known in the region. The first reliable data on faunas from this time interval have been obtained from the Beglitsa section, below the Mezin soil complex. This fauna (Beglitsa B) contains the characteristic species Arvicola chosaricus, with undifferentiated dental enamel, which indicates its attribution to the Khasarian faunal complex and local zone MQR2.

As was noted above, Late Pleistocene faunas are associated with upper levels of the loess-palaeosol sequence. No special study has so far been made of these faunas. The most concentrated material of this age is found in infillings of rodent burrows (krotovinas) that occur within palaeosol horizons. The few known elements include species indicative of dry steppe conditions. They are Lagurus lagurus, Stenocranius gregalis, dipodies and ground squirrels. In these settings the bones of small mammals co-occur with the remains of Mammuthus primigenius in Margaritovo 3 site (Bajgusheva et al., 2001). The rodent fauna is correlative with the Mammoth faunal complex and local zone MQR1.

\subsection{Geological events}

On the basis of geological, palaeontological and palaeomagnetic evidence, the main litho-stratigraphical units that have been established in the northeast of the Azov Sea area are as follows: Upper Pliocene, upper Lower Pleistocene, Middle and Upper Pleistocene (Fig. 6). Recognition of the Jaramillo Subchron in the Margaritovo and Port Katon sections allows refinement of the stratigraphy of the Lower-Middle Pleistocene transition.
The Jaramillo event is controlled by the Tamanian (late Early Biharian) small mammal faunas at the base and above the subchron.

The Upper Pliocene Khaprovian Formation is attributed to the palaeo-Don River sedimentation in its lower course and deltaic parts. Fig. 7a illustrates the widespread development of the Khaprovian Formation of Late Pliocene age $\left(\mathrm{N}_{2}^{3}\right)$. The Khaprovian Sands were essentially eroded during the Early Pleistocene, when the Apsheronian transgression penetrated this region from the east. According to the occurrences of marine molluscan fauna, the brackish-water Apsheronian sediments are represented in the submerged area to the southeast in the Eisk Penninsula, whereas lagoon sediments of the same age are widespread in the studied region (Fig. 7b).

Parallel with the Early Pleistocene lagoonal sedimentation, the red-brown 'Scythian' Clays were formed on the land. These clays overlie the Khaprovian Sands in the Liventsovka and Morskaya sections as well as the Pontian limestones along the northern coastal area of the Taganrog Gulf. It cannot be excluded that the red clays began to

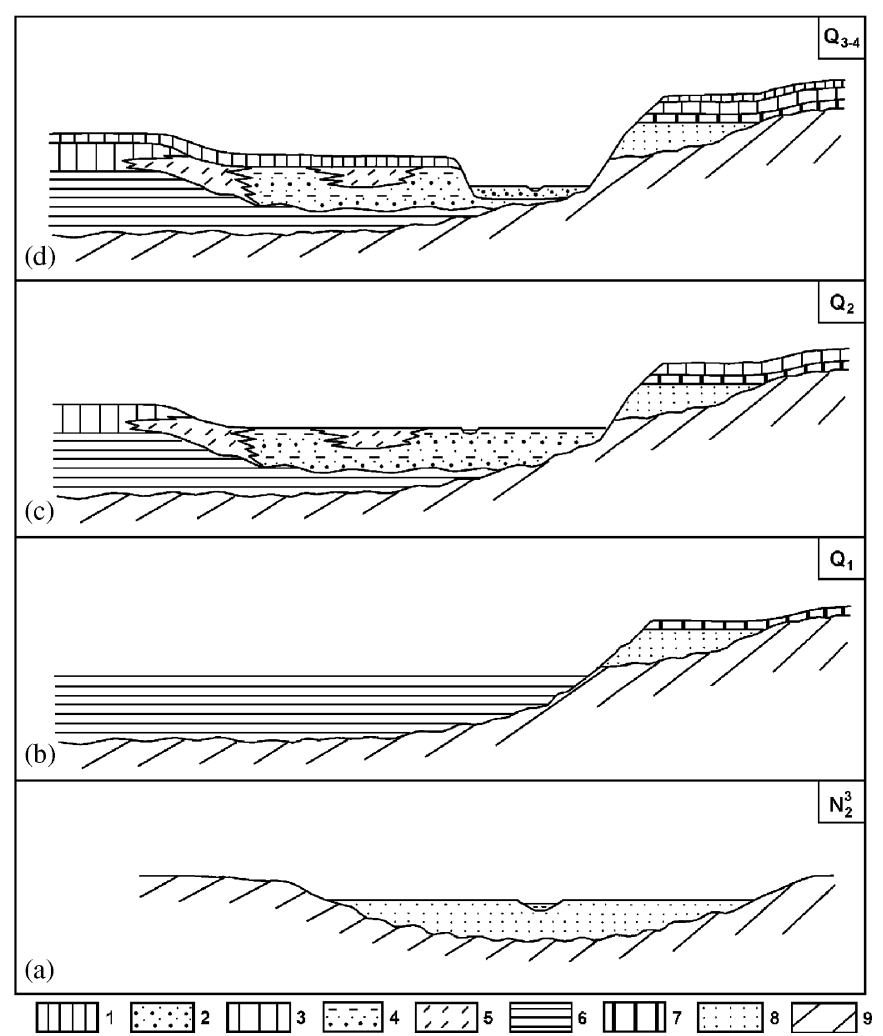

Fig. 7. Palaeogeological profiles along southeastern shoreline of the Taganrog Gulf and the mouth of River Don. (a) Late Pliocene, $\mathrm{N}_{2}^{3}$, Khaprovian Stage; (b) Early Pleistocene, $\mathrm{Q}_{1}$, Tamanian Stage; (c) Middle Pleistocene, $\mathrm{Q}_{2}$, Tiraspolian Stage; (d) Late Pleistocene and Holocene, $\mathrm{Q}_{3-4}$. $(1,2)$ Late Pleistocene: (1) loess-palaeosol series, (2) alluvial sand and gravel; (3-5) Middle Pleistocene: (3) loess-palaeosol series, (4) sands with layers of gravel and clay, (5) lagoonal loam; $(6,7)$ Early Pleistocene: (6) lagoonal clay, (7) red-brown subaerial clay; (8) Late Pliocene Khaprovian Sand; (9) bedrock. 
form long before the Early Pleistocene as a terra rossa formation after Miocene limestone deposits.

This was subsequently followed by a sea level fall and the progradation of the palaeo-Don delta at the beginning of the Middle Pleistocene. Deltaic sedimentation was developed in an extensive area from Semibalki to Kagal'nik, and probably up to the modern River Don bank at Liventsovka section in the north (Figs. 2, 7c). In some places the upper part of deltaic sequence shows a replacement of sands by loams and clays of fore-delta lakes, for example, in the Kagal'nik section. The loam bed here has yielded a skeleton of Mammuthus trogontherii. The orientation of bones, and especially of cranial elements, together with the relatively good preservation of bone material, indicates that the Mammuthus was buried where it died in a swampy lake (Bajgusheva, personal communication). The pollen analysis of the loams (Simakova, personal communication) containing the bone material suggests conditions of opensteppe landscapes in the palaeo-Don mouth area during the final stage of the deltaic sedimentation. To the south of Semibalki, the upper part of the deltaic sequence is replaced by the Middle Pleistocene subaerial loess formation with two or three palaeosols.

The Upper Pleistocene (Fig. 7d) loess sequence contains two palaeosol horizons, the Mezin and Bryansk buried soils, respectively. The formation of the Mezin pedocomplex corresponds to the Karangatian marine transgression in the Black Sea basin. On the basis of the drilling evidence, the top of the Karangatian deposits along the western coast and in the central part of the Azov Sea is generally recorded below sea level, at depths below $-10 \mathrm{~m}$ b.s.l. (Semenenko et al., 1991). This may account for the characteristic submergence of the Mezin pedocomplex below the sea level in the northwestern part of the Beglitsa outcrop and in the western part of the Platovo section. However, these deposits do occur in a relatively uplifted position $(0$ to $+7 \mathrm{~m})$ where Karangatian fossiliferous deposits occur at Kamennaya Balka, $15 \mathrm{~km}$ west of Rostov-on-Don (Tchepalyga et al., 2004).

The post-Mezin time is recorded by a relatively thick loess accumulation (7-8 $\mathrm{m}$ ). This represents a period of a complete drainage of the Azov Sea. The drained area was subjected to deflation processes and served as a source area of fine silty material for the subaerial sedimentation.

\section{Conclusions}

The present work is an important stage of geological studies in the region. The multidisciplinary approach adopted for the investigation of a number of key sections has resulted in detailed biostratigraphical and climatostratigraphical evidence for the sequence. The stratigraphy of the Middle-Late Pleistocene transition has been refined. This interval is shown to contain the palaeomagnetic Jaramillo Subchron, which is located in the upper part of the lagoonal sequence characterised by mammals of the Tamanian complex.
The small mammal fauna allows the determination of several biostratigraphical levels in the sedimentary sequence of the Azov Sea Region. So far the Late Pliocene, late Early Pleistocene, Middle Pleistocene and Late Pleistocene levels have been recognised. The corresponding Khaprovian-Psekupsian, Tamanian, Tiraspolian, Khasarian and Mammoth mammal complexes have been differentiated. Small mammal faunas, with numerous steppe lagurines, dipodines, ground squirrels, etc., indicate the important role of open landscapes throughout the entire Late Pliocene and Pleistocene history of the region. The presence of wooded and riparian biotopes along a major river (palaeo-Don) and coastal marine areas is indicated by the frequent occurrences of water vole $M$. savini, redbacked voles Clethrionomys, and desmans.

The wide distribution of the subaerial red ('Scythian') clays, specifically on the right bank of the Don River area in the zone of the submerged Azovian-Rostov segment of the eastern extension of the Ukrainian Shield, indicates a strong prevalence of continental conditions, at least since the Early Pleistocene. During the Early and Middle Pleistocene the area to the south of the modern River Don delta hosted lagoonal and deltaic sedimentation. This created favourable taphonomic conditions for the burial of mammalian remains.

The Middle and Late Pleistocene was a time of predominantly subaerial sedimentation. The corresponding loess sequence, exposed in coastal cliffs of the Taganrog Gulf, contains up to 5 palaeosols. Based on the available biostratigraphical control, the lower age limit of these palaeosols is no older than Middle Pleistocene. Their correlation with soil units of southern Russia and adjacent regions sequence is still tentative. The most reliable interpretation is possible for the two uppermost palaeosol levels that are correlated with the Bryansk palaeosol and the Mezin pedocomplex, respectively. The new data presented here confirms the high potential of the Azov Sea Region for the refinement of the Quaternary stratigraphy both at the regional and European scales.

\section{Acknowledgements}

We thank V.S. Bajgusheva, P. Haesaerts, G.I. Timonina, and E.A. Vangengeim for their stimulating discussions and for their help in the field. The authors are grateful to A.N. Simakova and A.L. Tchepalyga for palynological and mollusc expertise. The authors especially thank A.A. Gorbenko, Director of the Azovian Museum, for on-going support and hospitality. We are also grateful to the late M.A. Pevzner for providing geological information on the sections studied. We thank the reviewers, P.L. Gibbard and F. Masini, for their helpful remarks on the manuscript, as well as our thanks for the careful language correction go to P.L. Gibbard. This work was supported by RFBR projects nos. 02-05-64126, 02-05-39018. 


\section{References}

Agadjanian, A.K., 1976. Small mammals. In: Markov, K.K. (Ed.), Section of recent deposits of north-eastern part of the Azov Sea Region. Moscow State University, pp. 27-28, 65-67 (in Russian).

Alexandrova, L.P., 1976. Rodents of Anthropogene of the European part of the USSR. Nauka, Moscow, pp. 1-98 (in Russian).

Bajgusheva, V.S., 1971. Fossil theriofauna of the Liventsovka sandpit. In: Proceedings of the Zoological Institute of the USSR Academy of Sciences. St. Petersburg 49, pp. 5-29 (in Russian).

Bajgusheva, V.S., Timonina, G.I., 2001. Excavation of the skeleton of steppe or trogontherine elephant Mammuthus trogontherii (Pohlig, 1885) near Azov in 1999. Historical and archeological investigations in Azov and Lower Don River area in 1999-2000, no. 17, Azov Museum, Azov City, pp. 27-38 (in Russian).

Bajgusheva, V.S., Titov, V.V., Tesakov, A.S., 2001. The sequence of PlioPleistocene mammal faunas from the south Russian Plain (the Azov Region). Bollettino della Società Paleontologica Italiana 40 (2), $133-138$.

Cuenca-Bescós, G., Canudo, J.I., Laplana, C., 2001. La séquence des rongeurs (Mammalia) des sites du Pléistocène inférieur et moyen d'Atapuerca (Burgos, Espagne). L'Anthropologie 105, 115-130.

Dodonov, A.E., Tchepalyga, A.L., Mihailesku, C.D., Zhou, L.P., Markova, A.K., Trubikhin, V.M., Simakova, A.N., Konikov, E.G., 2000. Last-interglacial records from central Asia to the northern Black Sea shoreline: stratigraphy and correlation. Geologie en Mijnbouw 79 (2/3), 303-311.

Dubrovo, I.A., Alexeev, M.N., 1964. On the stratigraphy of Quaternary deposits of the Azov Sea Region. Bulletin of the Commission for the study of the Quaternary Period 29, 26-43 (in Russian).

Gromov, V.I., 1948. Palaeontological and archaeological implementation of stratigraphy of Quaternary continental deposits on the territory of USSR (mammals, Paleolithic). In: Proceedings of the Geological Institute of the USSR Academy of Sciences, vol. 64 (17), Moscow, 524 pp (in Russian).

Iossifova, Yu.I., Semenov, V.V., 1998. Climate-stratigraphy of the PreTiglian-Bavelian analogues in Central Russia (the Don drainage basin). Mededelingen Nederlands Instituut voor Toegepaste Geowetenschappen TNO 60, pp. 327-338.

Ivanova, I.K., Praslov, N.D., 1963. On the find of Mousterian nucleus in north coastal of Azov Sea. Bulletin of Moscow Society of Natural Research 37 (4), 97-100 (in Russian).

Kolfschoten, V.T., Markova, A.K., 2005. Response of the European mammalian fauna to the mid-Pleistocene transition. In: Head, M.J., Gibbard, P.L. (Eds.), Early-Middle Pleistocene Transitions: The LandOcean Evidence. Geological Society, London, Special Publications, vol. 247 , pp. 221-229.

Lebedeva, N.A., 1965. Geological settings of small mammal localities in the Antropogene of the Azov Sea Region. In: Nikiforova, K.V. (Ed.), Stratigraphical Significance of Anthropogene Fauna of Small Mammals. Nauka, Moscow, pp. 111-140 (in Russian).

Lebedeva, N.A., 1972. Anthropogene of the Azov Sea Region. Nauka, Moscow, pp. 1-106 (in Russian).

Markov, K.K., (Ed.)., 1976. Section of Recent Deposits of North-eastern Part of the Azov Sea. Moscow State University, pp. 1-157 (in Russian).

Markova, A.K., 1982. Pleistocene Rodents of the Russian Plain. Nauka, Moscow, pp. 1-182 (in Russian).
Markova, A.K., 1990. The sequence of Early Pleistocene small mammal faunas from the South Russian Plain. Quartärpaläontologie 8, $131-151$.

Markova, A.K., 2005. Eastern European rodent (Rodentia, Mammalia) faunas from the Early-Middle Pleistocene transition. Quaternary International 131, 71-77.

Maul, L., 2001. Die Kleinsäugerreste (Insectivora, Lagomorpha, Rodentia) aus dem Unterpleistozän von Untermaßfeld. In: Kahlke, R.-D. (Ed.), Das Pleistozän von Untermaßfeld bei Meiningen (Thüringen). Teil 3. Monographien des Römisch-Germanischen Zentralmuseums, vol. 40(3), Verlag Dr. Rudolf Habelt, Bonn, pp. 783-887.

Pevzner, M.A., Vangengeim, E.A., Tesakov, A.S., 2001. Quaternary zonal subdivision of Eastern Europe based on vole evolution. Bollettino della Società Paleontologica Italiana 40 (2), 269-274.

Popov, G.I., 1948. Tanais Beds of ancient Don. Bulletin of the Commission for the study of the Quaternary Period 12, 55-68 (in Russian).

Rekovets, L.I., 1994. Anthropogene Small Mammals of Southern East Europe. Naukova Dumka, Kiev, pp. 1-369 (in Russian).

Rekovets, L.I., Nadachowski, A., 1995. Pleistocene voles (Arvicolidae) of the Ukraine. Paleontologia i Evolucio 28-29, 145-245.

Rodzyanko, G.N., 1967. Pliocene of Lower Don and Lower Volga. In: Materials of Geological Studies in the Area of Lower Don and Lower Volga Rivers. Rostov State University, pp. 272-283 (in Russian).

Schevtschenko, A.I., 1965. Key complexes of small mammals from Pliocene and lower Anthropogene in the south-western part of the Russian Plain. In: Nikiforova, K.V. (Ed.), Stratigraphical Significance of Anthropogene Fauna of Small Mammals, pp. 7-57 (in Russian).

Semenenko, V.N., Vishnevetski, A.V., Petruk, V.A., Luparenko, A.V., Kovalukh, N.N., 1991. About marine Upper Pleistocene deposits of northwest part of the Kerch Peninsula. Geological Journal 3, 105-115 (in Russian).

Tchepalyga, A.L., Sadchikova, T.A., Leonova, N.B., Nesmeyanov, S.A., Pirogov, A.N., 2004. Caspian-Black Sea water exchange along the Manych-Kertch Strait in Late Pleistocene. In: Ecology of the Anthropogene and Recent Epoch: Nature and Humans. Humanistica, St. Petersburg, pp. 50-52 (in Russian).

Tesakov, A.S., 2004. Biostratigraphy of Middle Pliocene-Eopleistocene of Eastern Europe (based on small mammals). Nauka, Moscow, pp. 1-247 (in Russian).

Titov, V.V., 1999. Fauna of Late Pliocene Large Mammals of Northeastern Azov Sea Region. Palaeontological Institute, Moscow, pp. 1-24 (in Russian).

Velichko, A.A., 1975. Problems of Pleistocene events correlation in glacial, loess-periglacial and seaside areas of the East European Plain. In: The Problem of Palaeogeography of Loess and Periglacial Regions. Nauka, Moscow, pp. 7-25 (in Russian).

Velichko, A.A., Morozova, T.D., Pevzner, M.A., 1973. Structure and age of loess and fossil soil horizons on the main terrace levels of the northern Azov Region. In: Palaeomagnetic Analysis in the Study of Quaternary Deposits and Vulcanites. Nauka, Moscow, pp. 48-70 (in Russian).

Velichko, A.A., Markova, A.K., Morozova, T.D., Nechaev, V.P., Svetlitskaya, T.V., Tsatskin A.I., Chichagov, O.A., 1992. Geochronology of loess-palaeosol formation in South-West Russian Plain based on new data. In: Geochronology of the Quaternary. Nauka, Moscow, pp. 28-33 (in Russian). 